\title{
Mode of action of delta-9-tetrahydrocannabinol on hypothalamo-pituitary function in adult female rats
}

\author{
Indira Chakravarty, Parul G. Shah*, A. R. Sheth* and J. J. Ghosh $\dagger$ \\ Department of Food and Nutrition, V.L. College of Home and Social Sciences, Calcutta \\ University, Hastings House, Alipore, Calcutta 700 027; *Division of Biochemistry, Institute for \\ Research in Reproduction (ICMR), Jehangir Merwanji Street, Parel, Bombay 400 012; and \\ $\dagger$ Department of Biochemistry, Calcutta University, 35 Ballygunge Circular Road, Calcutta \\ 700019, India
}

\begin{abstract}
Summary. Administration of delta-9-tetrahydrocannabinol ( $\left.\Delta^{9}-\mathrm{THC}\right)$ to prooestrous rats $(5 \mathrm{mg} / \mathrm{kg}$ and $10 \mathrm{mg} / \mathrm{kg}$, i.p. for 10 days) decreased the hypothalamic LH-RH content. Serum prolactin levels were reduced but serum LH and FSH and pituitary hormone content were similar to values in dioestrous rats. It is suggested that $\Delta^{9}$-THC acts primarily on the hypothalamus.
\end{abstract}

\section{Introduction}

Several reports have appeared regarding disturbed reproductive function in female rats treated with tetrahydrocannabinol ( $\Delta^{9}$-THC) (Persand \& Ellington, 1967, 1968). Although some evidence is available that the drug alters circulating levels of hormones (Nir, Ayalon, Tsafriri, Cordova \& Lindner, 1973) the precise site of action, i.e. hypothalamus and/or pituitary, of the drug is not yet known. In the present study, the effect of $\Delta^{9}$-THC on the hypothalamic LH-RH, and serum and pituitary levels of $\mathrm{FSH}, \mathrm{LH}$ and prolactin was investigated.

\section{Materials and Methods}

Adult female rats of the Holtzman strain, weighing about $200 \mathrm{~g}$ and with regular 5-day cycles, were maintained in temperature $\left(26 \pm 1^{\circ} \mathrm{C}\right)$ - and light $(14 \mathrm{~h}$ light $/ 24 \mathrm{~h}$ )-controlled rooms. The rats were fed a standard pellet diet (Hindustan Lever) and always had access to water.

Pure $\Delta^{9}$-THC obtained from the United Nations Narcotics Laboratory was made into solution in saline $(9 \mathrm{~g} \mathrm{NaCl} / \mathrm{l})$ with a trace amount of Tween 80 for uniform suspension. Doses of 5 or $10 \mathrm{mg} \Delta^{9}-\mathrm{THC} / \mathrm{kg}$ body weight were injected intraperitoneally at 10:00 h every day for 10 consecutive days. The original concentration of the drug was $20 \mathrm{mg} \Delta^{9}-\mathrm{THC} / \mathrm{ml}$, and therefore each rat received $0.1-0.65 \mathrm{ml}$ solution. The control animals received an equal volume of the vehicle at the same times. For all animals, the injections were started on the day of prooestrus. A separate control group in which the animals were in dioestrus at the start of the experiment was also set up.

At the end of the experimental period, the rats were killed by decapitation between 10:00 and 11:00 $\mathrm{h}$ and the trunk blood was collected. The blood was allowed to clot for $2 \mathrm{~h}$ at room temperature and then placed in a refrigerator at $4^{\circ} \mathrm{C}$ for $24 \mathrm{~h}$. The serum was collected by centrifugation at $4^{\circ} \mathrm{C}$ and stored at $-20^{\circ} \mathrm{C}$ until used for hormone assays.

Hypothalami were dissected and homogenized in ice-cold $0.1 \mathrm{~N}-\mathrm{HCl}$, and centrifuged at $3000 \mathrm{~g}$ for $30 \mathrm{~min}$ at $4^{\circ} \mathrm{C}$. The supernatant was used for the measurement of LH-releasing activity as described by Goomer, Saxena \& Sheth (1977). Anterior pituitaries were incubated in 
Medium 199, pH 7.2 (Difco Laboratories, Michigan, U.S.A.), containing synthetic LH-RH (NIH, Bethesda, U.S.A.) or hypothalamic extract for $4 \mathrm{~h}$ at $37^{\circ} \mathrm{C}$ in a metabolic shaker, preceded by preincubation of pituitaries for $30 \mathrm{~min}$ without standard or samples. $\mathrm{LH}$ released into the medium was determined by radioimmunoassay. A standard curve for synthetic LH-RH was constructed on the basis of the amount of LH released/pituitary. A linear dose-response was obtained. The intra-assay variation was $7 \%$.

For in-vitro pituitary sensitivity, the pituitaries from the treated and the control rats were dissected out and pooled. Four pituitary halves were incubated with $250 \mathrm{ng} \mathrm{LH}-\mathrm{RH} / \mathrm{ml} \mathrm{Medium}$ $199, \mathrm{pH} 7 \cdot 2$, at $37^{\circ} \mathrm{C}$ in a metabolic shaker for $4 \mathrm{~h}$ after a $1 \mathrm{~h}$ preincubation period. The amount of $\mathrm{LH}$ released in the medium after incubation was measured by radioimmunoassay. Each observation was based on the results obtained from 3 pools and each pool was derived from 2-3 animals.

Concentrations of LH, FSH and prolactin were assayed by the methods of Monroe, Parlow. \& Midgley (1968), Daane \& Parlow (1971) and Niswender, Chen, Midgley, Meites \& Ellis (1969), respectively. The standards used were NIAMDD-rat-LH-RP1, NIAMDD-rat-FSHRP1 and NIAMDD-rat-prolactin-RP1. The reagents for the assays were supplied by the Rat Pituitary Distribution Program, NIAMDD, Bethesda, U.S.A. Serum samples were analysed at 3 dose levels using 20, 100 and $200 \mu \mathrm{l}$ aliquots. Pituitary and medium samples were diluted $1: 20$ with phosphate-buffered saline, $\mathrm{pH} 7 \cdot 2$. The inter- and intra-assay coefficients of variation were $12 \%$ and $5 \%$ respectively for all the assays. The sensitivities were $2 \mathrm{ng} \mathrm{LH}, 10 \mathrm{ng}$ FSH and 0.2 ng prolactin.

The significance of differences between means was determined by Student's paired $t$ test.

\section{Results}

The hormone levels obtained for the 4 groups of rats are shown in Table 1. All rats became acyclic.

\section{Changes in hypothalamic $\mathrm{LH}-\mathrm{RH}$}

$\Delta^{9}$-THC (Groups 3 and 4) lowered the levels of hypothalamic LH-RH significantly, compared with values in Groups 1 and 2.

\section{Changes in pituitary sensitivity to $\mathrm{LH}-\mathrm{RH}$}

$\Delta^{9}$-THC appeared to have no effect on the sensitivity of the pituitaries since the amounts of LH released during incubation with pituitaries were similar in all 4 groups.

Table 1. Effect of delta-9-tetrahydrocannabinol ( $\left.\Delta^{9}-\mathrm{THC}\right)$ in adult female rats

\begin{tabular}{|c|c|c|c|c|}
\hline & $\begin{array}{c}\text { Group 1 } \\
\text { (control pro-oestrous) }\end{array}$ & $\begin{array}{c}\text { Group } 2 \\
\text { (control dioestrous) }\end{array}$ & $\begin{array}{c}\text { Group 3 } \\
\left(5 \mathrm{mg} \Delta^{9}-\mathrm{THC} / \mathrm{kg}\right)\end{array}$ & $\begin{array}{c}\text { Group } 4 \\
\left(10 \mathrm{mg} \Delta^{9}-\mathrm{THC} / \mathrm{kg}\right)\end{array}$ \\
\hline $\begin{array}{l}\text { Hypothalamic LH-RH } \\
\text { (ng/hypothalamus) }\end{array}$ & $515 \pm 11.50$ & $446 \pm 9.82$ & $413 \pm 7.67^{*}$ & $321 \pm 11.04^{* * * *}$ \\
\hline $\begin{array}{l}\text { Pituitary sensitivity } \\
\text { ( } \mu \text { g LH released/pituitary) }\end{array}$ & $58 \pm 0.69$ & $53 \pm 0.94$ & $55 \pm 0.82$ & $56 \pm 2 \cdot 86$ \\
\hline $\begin{array}{l}\text { Pituitary content } \\
\text { LH ( } \mu \mathrm{g} / \text { pituitary) } \\
\text { FSH }(\mu \mathrm{g} / \text { pituitary) } \\
\text { Prolactin (ng/pituitary) }\end{array}$ & $\begin{array}{r}30 \pm 1 \cdot 14 \\
30 \pm 12 \cdot 30 \\
501 \pm 40 \cdot 20\end{array}$ & $\begin{array}{r}43 \pm 6 \cdot 13 \\
42 \pm 15 \cdot 80 \\
315 \pm 20 \cdot 10\end{array}$ & $\begin{array}{r}39 \pm 0.04 \\
53 \pm 2.50 \\
345 \pm 30 \cdot 10\end{array}$ & $\begin{array}{r}43 \pm 2.57 \\
56 \pm 6 \cdot 70 \\
395 \pm 32 \cdot 40\end{array}$ \\
\hline $\begin{array}{l}\text { Serum concentration } \\
\text { LH }(\mathrm{ng} / \mathrm{ml}) \\
\text { FSH }(\mathrm{ng} / \mathrm{ml}) \\
\text { Prolactin }(\mathrm{ng} / \mathrm{ml})\end{array}$ & $\begin{aligned} 342 & \pm 39 \cdot 5 \\
385 & \pm 31 \cdot 3 \\
73 & \pm 11 \cdot 60\end{aligned}$ & $\begin{array}{l}255 \pm 42.7 \\
352 \pm 11.9 \\
52 \pm 2.70\end{array}$ & $\begin{array}{l}261 \pm 8.20 \\
289 \pm 26 \cdot 0 \\
40 \pm 2.00^{* *}\end{array}$ & $\begin{array}{l}218 \pm 30 \cdot 1 \\
293 \pm 45 \cdot 5 \\
43 \pm 2 \cdot 60^{* *}\end{array}$ \\
\hline
\end{tabular}




\section{Changes in pituitary hormone content}

The control rats in Group 2 had higher contents of LH and FSH in the pituitary than did those in Group 1. Treatment with $\Delta^{9}$-THC had little effect on pituitary hormone content when compared to values for the control dioestrous rats in Group 2.

\section{Changes in circulating hormone levels}

Serum FSH and LH levels were lowered in Groups 3 and 4, compared with Group 1 values, but there was no difference from Group 2 values. Prolactin levels were similarly reduced in Groups 3 and 4 compared with Groups 1 and 2.

\section{Discussion}

The present results indicate that rats treated with $\Delta^{9}$-THC during pro-oestrus become hormonally similar to dioestrous rats, except for the reduction in serum prolactin, and the drug therefore causes prolongation of the oestrous cycle as indicated by Nir et al. (1973). Lowering of serum prolactin levels by the drug could be due to the antioestrogenic nature of $\Delta^{9}$-THC (Chakravarty, Sengupta, Bhattacharya \& Ghosh, 1976; Okey \& Bondy, 1977).

In spite of the alterations observed in the hormonal levels the in-vitro response of the pituitary to exogenous LH-RH was unaltered in $\Delta^{9}$-THC-treated animals and suggests that the pituitaries in these animals would be functioning normally. However, the drug significantly lowered LH-RH content in a dose-dependent manner and so the site of action of the drug may be primarily at the hypothalamus where it could be affecting the synthesis of LH-RH. Ayalon et al. (1977) have recently suggested that the action of $\Delta^{9}-\mathrm{THC}$ is probably exerted on the hypothalamus: our findings give the experimental evidence for this hypothesis.

\section{References}

Ayalon, D., Nir, I., Cordova, S., Bauminger, S., Poder, M., Naor, Z., Kashi, R., Zor, U., Harell, A. \& Lindner, H.R. (1977) Acute effect of delta-1-tetrahydrocannabinol on the hypothalamo-pituitaryovarian axis in the rat. Neuroendocrinology 23, 3142.

Chakravarty, I., Sengupta, D., Bhattacharya, P. \& Ghosh, J.J. (1976) Effect of cannabis extract on the uterine monoamine oxidase activity of normal and estradiol treatments. Biochem. Pharmacol. 25, 377378.

Daane, T.A. \& Parlow, A.F. (1971) Periovulatory patterns of rat serum follicle stimulating hormone and luteinizing hormone during the normal estrous cycle: effects of pentobarbital. Endocrinology 88, 653-663.

Goomer, N., Saxena, R.N. \& Sheth, A.R. (1977) Effect of neonatal testosterone and oestradiol treatment on the development of the hypothalamo-hypophysial axis in female rats. J. Reprod. Fert. 50, 239-248.

Monroe, S.E., Parlow, A.F. \& Midgley, A.R., Jr (1968) Radioimmunoassay for rat luteinizing hormone. Endocrinology 83, 1004-1012.

Nir, I., Ayalon, D., Tsafriri, A., Cordova, T. \& Lindner, H.R. (1973) Suppression of cyclic surge of LH secretion and ovulation in the rat by delta-9-THC. Nature, Lond. 243, 470-471.

Niswender, G.D., Chen, C.L., Midgley, A.R., Jr, Meites, J. \& Ellis, S. (1969) Radioimmunoassay for rat prolactin. Proc. Soc. exp. Biol. Med. 130, 793-797.

Okey, A.R. \& Bondy, G.P. (1977) Is delta-9-tetrahydrocannabinol estrogenic? Science, N.Y. 195, 904-905.

Persand, T.V.N. \& Ellington, A.C. (1968) Teratogenic early pregnancy. Lancet ii, 1306.

Persand, T.V.N. \& Ellington, A.C. (1968) Te ratogenic activity of cannabis resin. Lancet $\mathbf{i i}, 406-407$. 